\title{
(®) IJBEMP
}

International Journal of Business, Economics and Management Perspectives

Uluslararası İşletme, Ekonomi ve Yönetim Perspektifleri Dergisi

Yıl: 3, Cilt:2, Sayı: 2, Temmuz 2018, s. 44-54

KONAKLAMA İSLETMELERINDE ÇEVRESEL MALIYETLERIN SINIFLANDIRILMASI VE MUHASEBELEŞTİRILMESI ÜZERINNE BİR ARAŞTIRMA

\section{Dr.Öğretim Üyesi, Ali APALI}

Mehmet Akif Ersoy Üniversitesi, Zeliha Tolunay Uygulamalı Teknoloji ve İşletmecilik Yüksekokulu, aapali@mehmetakif.edu.tr.

\section{Öğretim Görevlisi, Mesut BOZCU}

Akdeniz Üniversitesi, Elmalı Meslek Yüksekokulu, mesutbozcu@akdeniz.edu.tr

\section{Yonca SAKNILI}

yoncacicek_93otmail.com 


\title{
KONAKLAMA İSSETMELERINDE ÇEVRESEL MALIYETLERIN SINIFLANDIRILMASI VE MUHASEBELEŞTİIILMESI ÜZERINE BİR ARAŞTIRMA \\ Özet
}

Gelişen ve gelişmekte olan ülkelerin ekonomilerini canlandırmaya olanak sağlayan turizm sektörü birçok çevresel etkiyi beraberinde getirmektedir. Bunun için turizm sektöründeki işletmeler gelişen rekabet koşullarına ayak uydurmak için bazı maliyetlere katlanmak durumundalar. Konaklama işletmelerinin gelişmesiyle birlikte ortaya çıkan çevresel maliyetlerin neler olduğu, bu maliyetlerin içsel ve dişsal maliyetler olarak sınıflandırılmasının yapılması araştırmanın başlangıcı olmuştur. Konaklama işletmelerinde çevresel maliyetlerin sınıflandırılarak nasıl muhasebeleştirildiğinin araştırılarak bir konaklama işletmesinin gerçek verileri ile incelenerek literatüre katkı sağlanması araştırmanın amacı olarak belirlenmiştir. Araştırmaya konu edinilen konaklama işletmesi Antalya İli sınırları içerisinde faaliyet gösteren yeşil yıldıza sahip bir konaklama işletmesidir. Çalışma sonucunda konaklama işletmelerinin çevre maliyetlerini nasıl sınıflandırdı̆̆ sonucunda çevresel maliyetler ile ilgili muhasebe kayıtlarından örneklerle çalışma sonuçlandırılmıştır.

Anahtar Kelimeler: Konaklama İşletmeleri, Çevresel Maliyetler, İçsel Çevresel Maliyetler, Dişsal Çevresel Maliyetler.

\section{A RESEARCH ON THE CLASSIFICATION AND ACCOUNTING OF ENVIRONMENTAL COSTS IN ACCOMMODATION BUSINESSES}

\begin{abstract}
The tourism sector, which enables the revitalization of developing and developing countries' economies, brings together many environmental impacts. For this reason, the companies in the tourism sector must bear some costs in order to keep up with the developing competition conditions. What are the environmental costs associated with the development of accommodation establishments, the classification of these costs as internal and external costs has been the beginning of the research. After examining the environmental costs in the accommodation establishments and how they were accounted for, it was determined as the aim of the study to contribute to the literature by analyzing the actual data of an accommodation business. The accommodation business, which is the subject of the study, is a green-star accommodation establishment operating within the borders of Antalya. As a result of the study, how the accomodation enterprises classify the environmental costs and the examples related to the environmental costs as a result of this classification were taken from the accounting records and the study was finalized.
\end{abstract}

Key Words: Accommodation Management, Environmental Costs, Internal Environmental Costs, External Environmental Costs. 


\section{GİRIŞ̧}

Çevre, gelecek nesillerin emaneti olan bir kavramdır. Bu çerçevede gelişen ve gelişmekte olan işletmelerin çevreye vermiş olduğu zararlar nedeniyle gerek içsel, gerekse dişsal çevresel maliyetlere katlanmak zorundadır. İşletmelerin çevresel faaliyetlerinin zararlı etkilerini minimize etmek ya da bu çevresel faaliyetleri önleme amacıyla bir takım girişimlerde bulunmaktadır. Burada muhasebe ilkelerinden olan sosyal sorumluluk ilkesi devreye girmektedir. Muhasebe birimi işletmeleri çevreyle ilgili tehlikelere karşı bilgi üretme sorumluluğunu ortaya çıkarmaktadır. Muhasebe, çevrenin önemliliğini, daha çok ortaya çıkararak çevreye karşı duyarlı işletmeler oluşturmaya çalışmaktadır.

Konaklama işletmelerinde çevresel maliyetlerin çevreye etkileri, bu çevresel maliyetlerin işletme açısından katlanmış olduğu maliyetlerin sınıflandırılması ve bu sınıflandırma sonucunda ortaya çıkan verilerle muhasebe kayıtlarının incelenmesi bu çalışmada gerçekleştirilmiştir.

\section{KAVRAMSAL ÇERÇEVE}

İşletmelerin temel işlemlerinden olan muhasebe, "işletmelerde meydana gelen finansal nitelikli olay ve işlemleri gözlemleyen, para birimi şeklinde sistemli bir şekilde tespit eden ve bunlara ilişkin bilgi ve belgeleri toplayan, kaydeden, sınıflandıran ve anlamlı olarak özetleyen, raporlayan ve sonuçları yorumlayarak ilgili kişi ve kuruluşlara sunan, bilim, sanat ve tatbikattı"” (Atabey vd.2001:8 aktaran Alagöz ve Baki, 2001: 150). Muhasebe sosyal sorumluluk kavramı gereği toplumun çıkarlarını göz önünde bulundurmaktadır. Sosyal sorumluluk muhasebesinin alt gurubunu oluşturan çevre muhasebesi, çevre için yapılan harcamaların belgelenmesi, raporlaması ve denetlemesi olarak karşılık bulmaktadır.

Çevre muhasebesi," çevresel kaynakların oluşumunu, bu kaynakların kullanılma biçimini, örgütlerin işlemleri sonucunda bu kaynaklarda meydana gelen artış veya azalışları ve örgütlerin çevresel açidan bilgileri üreten ve bunları ilgili kişi ve kuruluşlara ileten bir bilgi sistemidir" Çevre muhasebesi, ürettiği bilgilerle ekonomi ve çevre arasında etkileşim kurmayı amaçlamaktadır (Kırlığlu ve Can, 1998: 56). Çevre muhasebesinin diğer amaçları şu şekilde sıralanmaktadır (Tanc1, 2012: 38);

- Geleneksel muhasebe uygulamalarının olumsuz etkilerini ortadan kaldırmak için araştırmalar yapmak,

- Geleneksel muhasebe sistemi içinde, çevresel maliyetleri ve gelirleri ayrı olarak tanımlamak,

- İşletmenin hem iç hem dış çıkar grupları için, yeni performans ölçüm raporları, formları geliştirmek,

- Yönetim kararlarında daha fazla çevresel yararlılık elde edebilmek için yeni finansal veya finansal olmayan muhasebe, bilgi ve kontrol sistemleri oluşturmak,

- Çevresel sorunların etkisine ilişkin sosyal anlayışı işletmenin finansal yapısına ve yıllık hesaplarına yansitmak,

- Çevresel faaliyetleri denetim raporlarına eklemek,

- Çevresel raporlamanın ve çevre muhasebesi sisteminin geliştirilmesine katkı sağlayacak teori ve uygulamalara ağıllık vermek,

- Çevresel beyan ve raporların denetlenmesine/incelenmesine katkı sağlamak,

- Çevresel karar verme, yönetim sistemlerini değerleme gibi denetimle ilgili diğer hizmetlere katkı sağlamak

Maliyet bir amaca ulaşmak için ekonomik olarak katlanılan işlemlerin tümüdür. Çevresel maliyetler işletmelerin mal ve hizmetlerini sunabilmek için katlanılan maliyetler olarak tanımlanabilir. İşletmelerin çevre için yaptığı faaliyetler, çevresel maliyetleri ortaya çıkarmaktadır.

Çevre muhasebesinin işletmelere; çevresel sorunların etkisine ilişkin sosyal anlayışın işletmenin finansal yapısına ve yıllık hesaplarına yansıtılmasında, çevresel sorunların denetim programına dahil edilmesinde, çevresel raporların ve çevre muhasebesi sisteminin gelişimine katkı sağlayacak teori ve uygulamalarında ve çevresel beyan ve raporların denetlenmesine, incelenmesine katkı sağlamasında ve çevresel karar verme, yönetim sistemlerini değerleme gibi denetimle ilgili diğer hizmetlere katk1 sağlamaktadır (Dalgar ve Yıldırım, 2016: 3).

Turizm sektörü ülkelerin önemli gelir kaynaklarını oluşturmaktadır. İstihdam ve gelir olarak önemli bir yere sahip olan bu sektörü canlandırabilmek için işletmeler bu yönde daha fazla harcama yapmaya başlamışlardır. Turizm sektörü gelişirken beraberinde olumlu ve olumsuz etkilere neden olmaktadır. Olumlu çevresel etkiler, sosyal ve ekonomik çevre üzerinedir. Turizmin gelişmiş olduğu bölgelerde istihdam artmaktadır. Çünkü konaklama işletmelerinin oluşumunda inşaat sektörü, 
tedarikçiler için iş imkânı sağlar, işgücünü yerel halktan sağlar ve bunun gibi iş olanakları sunmasının yanında olumsuz birçok etkisi de bulunmaktadır. Bu olumsuzluklar şu şekildedir; (Aslanertik ve Özgel, 2007: 165).

- Konaklama işletmelerinin oluşumu sırasında doğal alanların zarara uğraması, yok olması,

- Doğal alanların azalmasıyla birlikte betonarmenin artması,

- Konaklama işletmelerinin çevrelerinin düzenlenmesi için ağaçlık alanların tahrip edilmesi,

- Konaklama işletmelerinin inşaatlarında ortaya çıkan moloz ve inşaat atıkları

- Konaklama işletmelerinin oluşturduğu evsel çöpler,

- Atıkların denize ya da nehir sularına dökülmesi

- Bahçe sulama, havuz doldurmak için artezyenlerden aşırı su çekimi ile yer altı su kaynaklarının azalması,

- Çamaşır yıkamada çıkan kimyasal kokuların doğaya zararı,

- Turistlerin konaklama işletmesi içinde ve konaklama işletmesi dışındaki çevreye attıkları atıklar

- Turistleri konaklama işletmesine getiren araçların havaya yaymış olduğu egzoz dumanı,

- Turizmin fazla olduğu bölgede ulaşım kolaylığı için dolmuş sayılarının artırılması,

- Isıtma ve soğutma için kullanılan sistemlerde yer alan gazların havayı kirletmesi,

- Eğlence merkezlerinin artmasıyla birlikte gürültü kirliliğinin artması,

- Tarihi güzelliklerin yeniden restore edilmesiyle birlikte ortaya çıan kirlilik, kötüleşmesi,

Çarpık kentleşme ile arkeolojik ve tarihi yerlerin ve yeşil alanların tahrip edilmesiyle oluşan manzaranın

- Turizmin geliştiği bölgelerde yerleşmenin artmasıyla birlikte alt yapı sorunlarının artması,

- Kıyı yapılaşmasıyla birlikte bazı canlı türlerinin üreme ortamlarının tahrip edilmesi,

- Bacalardan çıkan dumanların ekosisteme zararı,

- Konaklama işletmelerinde kullanılan kimyasal temizlik maddelerinin çevreye etkisi,

- Isıtma ve soğutma için kullanılan sistemlerde yer alan gazların havayı kirletmesi,

$\mathrm{Bu}$ nedenler arttırılabilir. Bunun için çevreye olan zararı azaltmaya yönelik düzenlemeler yapılarak doğaya olan etkisinin büyüklüğüne ve önemine dikkat çekmelidir.

Konaklama endüstrisi, insanların konutlarından farklı nedenlerle yaptıkları sürekli olmayan konaklama, yeme-içme, gezi, spor ve eğlence gibi ihtiyaçların karşılanabilmesi noktasında mal ve hizmet üreten sosyal ve ekonomik işletmelerdir (Bekçi, 2003: 1). Bu bağlamda konaklama işletmeleri, farklı şekillerde doğal çevreyle etkileşimde bulunduğu bilinmektedir. Bu durum sonucunda, doğal çevreye zarar verdiği saptanmaktadır (Kirk, 1998: 33 aktaran Mutlu ve Yıldız 2015: 110). Çevre yönetimi, doğal kaynaklara, alanlara zarar vermemek ve çevrenin sürdürülebilirliğini sağlamak için alınan kararların uygulanması olarak açıklanmıştır. İşletmelerin gerçekleştirdiği faaliyetlerin, bulundukları alanlara olumlu veya olumsuz olan etkilerinin tespit edilmesi ve ortaya çıkan sonuçlara göre çevreye duyarlı uygulamalar gerçekleştirmeleri gerektiği vurgulanmıştır (Mutlu ve Yıldız 2015: $110)$.

Turizm sektörünün paydaşı olan tarafların birtakım beklentileri bulunmaktadır. Bunları temiz çevre, korunmuş tarihi ve doğal güzellikler, ulaşım kolaylığı, altyapı hizmetleri, güvenli ortamlar, iletişim kolaylığı olarak sıralamak mümkündür. Bu tür beklentiler çevre paydaşlarının daha çok bilinçlenmesini sağlamaktadır.

Konaklama işletmelerinde maliyetlerin büyük kısmı işletmelerin kurulmasından işletmesinin açılışına kadar geçen sürede katlanılan maliyetlerdir. Konaklama işletmelerini diğer işletmelerden ayıran farklı özellikler bulunmaktadır. Bu farklılıklar finansal tablolar yardımıyla ortaya konabilir (Atmaca ve Y1lmaz: 2011:20)

\section{LITERATÜR TARAMASI}

Konaklama işletmelerinde çevre muhasebesi başta olmak üzere literatürde çevre muhasebesi ile ilgili bazı çalışmalar bulunmaktadır. Bu çalışmalardan örnekler aşağıda sıralanmıştır.

Alagöz ve Yılmaz (2001), çevre muhasebesi ve çevresel maliyetler üzerine bir çalışma gerçekleştirmişlerdir. Bu çalışmanın sonucu olarak, çevre muhasebesi sisteminin kurulması ve bu sistemin gelişmesine bağlı olarak çevre yönetim sisteminden elde edilecek bilgi ve analizlerin çevresel maliyetlere bağlı olacağını belirtmişlerdir. 
Aslanertik ve Özgen (2007) konaklama işletmelerinin çevresel anlamda nasıl etkilendiğini ve bu etkilerin maliyetlerinin sınıflandırılması üzerindeki etkilerini araştırmıştır. Bu çalışma konaklama işletmelerinin içinde bulundukları zarara karşı1ık nasıl önlem alması gerektiğiyle ilgili bir çalışmadır. Araştırma sonucunda çevreye verilen zararın önüne geçilmez ise en büyük zarara yine konaklama işletmelerinin uğrayacağını belirtmişlerdir.

Lazol, Muğal ve Yücel (2008) Bursa' da bulunan KOBİ'lerin sürdürülebilir bir çevre ve çevre muhasebesine yönelik bir çalışma yapmışlardır. Bu çalıma sonucunda KOBİ'lerin \% 67'sinin çevre muhasebesini uyguladıkları, \% 33'ünün ise uygulamadığı sonucuna varılmıştır. Buna göre muhasebe işletmelerinin sosyal sorumluluk kavramını yerine getirmeleri gerektiği sonucuna varılmıştır.

Çetin, Özcan ve Yücel (2011), çevre, çevre muhasebesi ve çevresel maliyetler ile ilgili bir derleme çalışması yapmıştır. Bu çalışma sonucunda çevresel sorunların çevreyi tehdit etmesiyle değer kazanmaya başlayan çevre ve çevre muhasebesi ile ilgili teorik bilgi vererek literatüre katk1 sağlamışlardır.

Atmaca ve Y1lmaz (2011) konaklama işletmelerinin faaliyetlerinde maliyet kontrolünün etkileri ile ilgili Marmara Bölgesi'nde bulunan bir konaklama işletmesine yönelik bir uygulama ortaya koymuşlardır. Bu çalışma sonucunda, konaklama işletmelerinin maliyet kontrolünün sağlanmasına yönelik gerçekleştirilen işletme faaliyetlerine, muhasebe ve maliyet muhasebesi uygulamalarına yaklaşımlarının pozitif yönde olduğu tespit edilmiştir.

Korukoğlu (2011), çevre muhasebesi çalışmalarının çalışanlar üzerindeki olumlu etkilerinin çevre muhasebesinin işletmelerde ne şekilde uygulandığını araştırmak amaçlanmıştır. Bu çalışmada çevre muhasebesinin daha çok iş süreçlerinde verimlilik gibi hususlarda etkili olduğu görülmüştür. Çevresel etki ve atık emisyonu ile ilgili fayda ikinci ve üretilen mal ve hizmetlerin faydası ise üçüncü sırada yer aldığ 1 tespit edilmiştir.

Aydın (2012), çevre muhasebesinin yaygın olarak kullanıldı̆̆ Birleşik Krallık'ta faaliyet gösteren konaklama işletmeleri ile Türkiye'de faaliyet gösteren konaklama işletmelerini incelemiş ve birbirleri ile karşılaştırmıştır. Bu çalışmanın sonucunda aslında konaklama işletmelerinin yıldızlarının çok olmasının bir önemi olmadığı çevresel sistemlerinin olup olmadığının daha önemli olduğu saptanmıştır. Bu uygulamada Türkiye'de ve Birleşik Krallık'ta faaliyet gösteren konaklama işletmelerinin satınalma, su kullanımı, enerji kullanımı ile atık yönetimine ilişkin kararlarda çevreye duyarlılıkları arasında farklılık olduğu belirlenmiştir.

Sancar, Kutukız ve Uslu (2015), Güney Doğu Anadolu bölgesinde faaliyet gösteren konaklama işletmelerinin çevre muhasebesine bakış açıları ve çevre muhasebesine olan uyumlarını araştırmışlardır. $\mathrm{Bu}$ çalışmanın sonucunda çevresel sorunların çözümünde işletmelere büyük sorumluluk düştügünü ve çevre sorunlarının önemli bir boyuta ulaşmasıyla işletmelerin çevreye karşı daha duyarlı olmaya başladıkları sonucuna ulaşmışlardır.

Dalgar ve Yıldırım (2016) konaklama işletmelerinin çevresel maliyetlerinin nasıl sınıflandırılacağının ve muhasebeleştirileceğinin üzerine bir araştırma gerçekleştirmiştir. Yapılan çalışma sonucunda konaklama işletmelerinin çevresel maliyetleri 7'li hesaplarda takip edilmesi, çevresel maliyetler ile diğer maliyetlerin tamamını görebilmeye olanak sağladığı belirtilmiştir.

Aksu ve Özcan (2018), Çanakkale'de bulunan termal turizm işletmeleri ile diğer konaklama işletmelerinin maliyet yönetimi açısından karşılaştırılması üzerine bir araştırma yapmışlardır. $\mathrm{Bu}$ çalışmanın sonucunda termal turizm işletmelerinin direkt ilk madde ve malzeme giderlerinin diğer konaklama işletmelerinin direkt ilk madde ve malzeme giderlerine göre toplam maliyetler içerisinde daha az paya sahip olduğu ortaya çıkmıştır. Çalışmaya katılan işletmelerin büyük çoğunluğunun maliyet kontrol ve yönetiminde geleneksel maliyet yöntemleri içerisinde yer alan fiili maliyet sistemini uyguladığı belirlenmiştir. 


\section{ANTALYA İLI'NDEKİ X KONAKLAMA İŞLETMESINIIN ÇEVRESEL MALIYETLERİ ÜZERINE BİR ARAŞTIRMA}

\subsection{Araştırmanın Konusu}

Konaklama işletmelerinde çevresel maliyetlerin önemi ve bu maliyetlerin sınıflandırılması ele alınarak konaklama işletmelerinin içsel ve dışsal çevre maliyetleriyle birlikte konaklama işletmelerindeki takibi araştırmanın konusu olmuştur.

\subsection{Araştırmanın Amacı}

Araştırmanın amacı, konaklama işletmelerinin çevreyle olan etkileşimleri sonrasında ortaya çıkan maliyetlerin içsel ve dışsal maliyet olarak sınıflandırarak, çevre muhasebesi ile ilgili ayrıca maliyet hesaplarının bulunmaması nedeni ile ortaya çıkan çevresel maliyetlerin nasıl muhasebeleştirildiği, çevresel maliyetlerin hangi hesaplar altında takip edildiğinin araştırılması bu çalışmanın amacı olarak belirlenmiştir.

\subsection{Konaklama İşletmelerinde Çevre Muhasebesinin X Konaklama İşletmesindeki Uygulaması}

Araştırmada incelenen konaklama işletmesi, Antalya İli’nde faaliyet gösteren dört şubesi olan bir işletmedir. Araştırma verileri 2017 ve 2018 yıllarına aittir. Araştırmanın gerçekleştirildiği konaklama işletmesi "ISO 14001" sahiptir. Ayrıca çevre denetim için "Mavi Bayrak Belgesi"ne, "Yeşil Yıldız Belgesi”ne sahip olmasının yanında, gıda güvenliği için “ISO 22000 Gıda Güvenliği Sertifikası”na da sahiptir.

Araştırmada yer alan veriler bizzat konaklama işletmesinden alınan gerçek veriler olup, bu veriler çevresel maliyetlerin içsel ve dışsal sınıflandırmasının yapılması sonrasında aşağıda sırası ile yer almaktadır.

\subsection{1. İçsel Maliyetler}

İçsel maliyetler, işletme faaliyetleri ile birlikte ortaya çıkan maliyetlerdir. Bu maliyetler geleneksel maliyetler, gizli maliyetler, şarta bağlı maliyetler ve imaj maliyetleri olarak sinıflandırılmaktadır (Apalı ve Bozcu, 2018);

\subsubsection{Geleneksel Maliyetler}

Hammadde kullanımı dışarıdan sağlanan fayda ve hizmetler, sermaye malları tedarik maliyeti genellikle maliyet muhasebesinde ve yatırım planlamasında yer alır. Ancak çevresel maliyetler göz önünde bulundurulmaz. Daha az hammadde atığı, dışarıdan sağlanan fayda ve hizmetler sermaye malları ve tedarik kullanımının azalması, çevresel zarar ve yenilenemez kaynakların tüketiminin azalması çevresel açıdan tercih edilir. İşletmeler karar alırken bu maliyetlerden faydalanır. Sermaye ekipmanı, malzeme, işçilik, donanım, dışarıdan sağlanan fayda ve hizmetler, binalar hurda değer maliyetleridir. (Aslanertik ve Işıl, 2007: 173; Tanc1, 2012: 50-51). Konaklama işletmesi bu maliyete uygun olarak yenilenebilir enerji elde etmek amacı ile ilave bir maliyete katlanmıştır. Konaklama işletmesi 2017 yılında temiz enerji elde etmek ve elektrik enerjisi maliyetlerini düşürmek amacıyla kendi aktifinde bulunan konaklama işletmesinin çatısına güneş enerjisi sistemi yaptırmıştır. Bunun için \% $18 \mathrm{KDV}$ hariç 200.000-TL maliyete katlanmış ve işletme şu şekilde kayıt altına almıştır.

\begin{tabular}{|l|r|r|r|}
\hline 256 DİĞER MADDİ DURAN VARLIKLAR & 200.000 & \\
256.01 Çevresel Maddi Duran Varl1lar & & \\
256.01.52 Binalar & & \\
256.01.52.01 Otel Binas1 & & 36.000 & \\
191 İNDIRILECEK KDV ÇEKLERVE & & 236.000 \\
ÖD.EMIRLERI $\quad 103 \quad$ VERİLEN & & \\
\hline
\end{tabular}

\subsubsection{Gizli Maliyetler}

Gizli maliyetler kendi içinde yasalar gereği zorunlu maliyetler, özel maliyetler, görünmeyen maliyetler ve isteğe bağlı maliyetler olarak dörde ayrılmaktadır. 
- Yasalar gereği zorunlu maliyetler: Yasal düzenlemelere dayanan maliyetler, işletmelerin faaliyet gösterdikleri iş koluna, faaliyet alanına, faaliyet bölgesine, yerleşik olduğu ülkenin yasal düzenlemelerine göre katlanmak zorunda oldukları maliyetlerdir. Yasal düzenlemelerden kaynaklı maliyetlere, ses yalıtım maliyetleri, maske gibi koruyucu malzeme kullanma zorunluluğuna bağlı olarak ortaya çıkan maliyetler, atık yönetimi maliyetleri, geri dönüşümlü malzeme kullanma zorunluluğundan kaynaklı maliyetler örnek olarak verilebilir. (Apalı ve Bozcu: 2018). Araştırmada incelenen yeşil yıldızı olan konaklama işletmesinin Çevre Bakanlığı'nca yayınlanmış yönetmelik gereğince çevreye verilecek zararın önlenmesi ve en aza indirilebilmesi için atıkları; organik atıklar, tıbbı atıklar, plastik atıklar ve geri dönüşümlü atıklar olarak ayrıştırmak istemektedir. Bunun için konaklama işletmesi 2018 yılında atık ayrıştırma sistemi kurmuş olup, bu sistem için işletme \%18 KDV hariç 120.000 TL'lik maliyete katlanmıştır. Bu veriye göre konaklama işletmesi şu şekilde bir kayıt gerçekleştirmiştir.

\begin{tabular}{|l|r|r|}
\hline 256 DİĞER MADDİ DURAN VARLIKLAR & 120.000 & \\
256.01.53.02. Atık Ayriştırma Tesisi & 21.600 & \\
191 İNDİRILECEK.KDV HS. & & 141.600 \\
$\quad 102$ BANKALAR HS. & & \\
\hline 102.01 .1 Y Bankasi & & \\
\hline
\end{tabular}

- Özel Maliyetler: Bu maliyetler işletmeden işletmeye, ülkeden ülkeye değişebilen çevresel maliyetlerdendir. Örneğin bir ülkede kullanılan bir ürünün başka bir ülkede kullanımının engellenmesi ve bu engel karşısında yerleşik olan işletmelerin daha fazla maliyete katlanması özel maliyettir. Dolayısıyla özel maliyetler işletmelerin kendi faaliyetleri sonrasında ortaya çıkan maliyetlerdir. $\mathrm{Bu}$ maliyetlerle ilgili örnekleme konu olan konaklama işletmesi çevreye olan zararı azaltmak için işletme yönetimi barlarında ve otel dışındaki restoran ve barlarında yiyecek-içecek bölümlerinde plastik tabak ve bardak yerine çevreye duyarlı, çevreyi kirletmeyen ve geri dönüşüm imkânı olan köpük tabak ve bardak kullanmaya karar vermiştir. Bu nedenle konaklama işletmesi bu malzemeler için \%18 KDV hariç 5.000 TL nakit ödemiştir.

\begin{tabular}{|l|r|r|}
\hline 150 İLK MADDE VE MALZEME & 5.000 & \\
15.04 Ambalaj Malz. & & \\
191 İNDİRILECEK.KDV HS. & 900 & \\
$\begin{array}{l}\text { 191.01.03 \%18 İndirilecek KDV } \\
\text { 100 KASA HS. } \\
\text { 100.01. TL Kasa }\end{array}$ & & 5.900 \\
\hline
\end{tabular}

- Görünmeyen Maliyetler: Bu maliyetler işletmelerin faaliyetleri sırasında ortaya çıkması muhtemel maliyetlerdir. Ortaya çıkma riski olması dolayısı ile önceden maliyetlerin artmasını ya da faaliyetlerin yarım kalmasının önüne geçilmesi için katlanılan maliyetlerdir. Tesis makine ve cihazların bakımının yapılması, yararlı ömrünü tamamlamadan, eskime ve yıpranmaya bağlı olarak makinelerin yenilenmesi veya gerekli önlemlerin önceden alınması olası riskleri ortadan kaldıracaktır. Bu doğrultuda gerçekleşen maliyetlere görünmeyen maliyetler olarak ifade edilmektedir. Görünmeyen maliyet kapsamında konaklama işletmesi elektrik kesintilerine karşı önlem alabilmek ve acil durumlardaki kesintilerin önüne geçebilmek için Jeneratörlerin 2018 yılı bakım onarım maliyeti olarak \%18 KDV hariç 10.000 TL'yi bankadan ödeme yapmıştır. Bu kaydı şu şekilde gerçekleştirmiştir.

\begin{tabular}{|l|r|r|}
\hline 740 HİZMET ÜRETIM MALIYETI & 10.000 & \\
740.05.03 Bakim Maliyeti & 1.800 & \\
191 İNDIRILECEK.KDV HS. & & \\
$\begin{array}{l}\text { 191.01.03 \%18 İndirilecek KDV } \\
\quad \text { 102 BANKALAR } \\
\text { 102.01.1 Y Bankas1 }\end{array}$ & & 11.800 \\
\hline
\end{tabular}

- İsteğe Bağlı Maliyetler: İsteğe bağlı maliyetler, işletmelerin yasal düzenlemelere uyma zorunluluğunda olmayıp, işletmelerin kendilerinin gönüllü olarak gerçekleştirdikleri maliyetlerdir. Örneğin, işletmelerin ağaçlandırma çalışmalarına katılmaları, çevre temizleme organizasyonlarına 
kaynak aktarmaları isteğe bağlı maliyetlerdir. Bu sınıflandırmada katlanılan maliyetler gönüllük esasına dayandığı için bir alt ya da üst sınıra tabi değildir. İşletmelerin tabi oldukları kanunlar çerçevesinde yönetim kararları doğrultusunda belirlenen maliyetlerdir (Apalı ve Bozcu: 2018). Bu doğrultuda işletme, Kundu Turizm Yatırımları Birliği tarafından düzenlenen "Temiz Sahiller" platformu için deniz tabanı ve deniz yüzeyi temizliği için ayrılan fon tutarı olan 15.000 TL'yi ilgili birliğe ödemiş ve şu kaydı yapmıştır.

\begin{tabular}{|c|r|r|}
\hline $\begin{array}{r}\text { 740 HİZMET ÜRETIMM MALIYYTI } \\
\text { 740.05.01 Temizlik gideri }\end{array}$ & 15.000 & \\
100 KASA HS. & & 15.000 \\
100.01. TL Kasa & & \\
\hline
\end{tabular}

\subsubsection{3. Şarta Bağlı (Koşullu) Maliyetler}

Gelecekte ortaya çıkması kesin olmayan maliyetlerdir. Gelecekteki atık salınımının önlenmesi için katlanılan maliyetler, geleceğe uyum maliyetleri, hata maliyetleri bu maliyetlere örnek olarak gösterilebilir. Bu maliyetler şarta bağlı yükümlülük maliyetleri olarak da ifade edilebilir (Çetin vd., 2004: 71). Bu doğrultuda konaklama işletmesi çevrenin gelecek nesillere ait olduğu anlayış1 ile faaliyette olan merkezi sistem klimalarında kullanılan gazların gerekli kontrollerde çevre dostu gazlardan olmadığı ortaya çıktığı için tüm merkezi klima sistemi çevre dostu gazlı olarak yenilenme kararı almıştır. Bu amaçla $400.000 \mathrm{TL}+\% 18 \mathrm{KDV}$ tutarında harcama yapılmış ve bedeli bankadaki hesaptan ödenmiştir. Bu doğrultuda şu şekilde bir kayıt gerçekleştirmiştir.

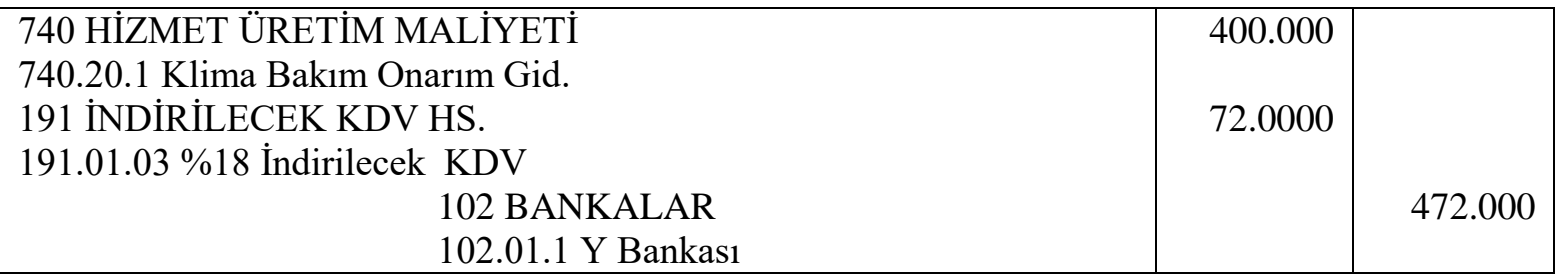

\subsubsection{4. İmaj Maliyetleri}

İşletmenin imaj oluşturmak ve dış çevresiyle ilişkilerini devam ettirmek için katlandığ 1 işletme imajı, müşterilerle ilişkiler, yatırımcılarla ilişkiler, sigortacılarla ilişkiler, beyaz yakalı personelle ilişkiler, mavi yakalı personelle ilişkiler, tedarikçilerle ilişkiler, kredi verenlerle ilişkiler, yerel topluluklarla ilişkiler, düzenleyici kişi ya da kurumlarla ilişkiler sonucunda ortaya çıkan maliyetlerdir (Kurtlu: 2017: 314). Konaklama işletmesi de bu maliyet kapsamında "temiz futbol, temiz çevre" sloganıyla bir futbol turnuvası düzenleyerek çevresel bir imaj kampanyası oluşturmayı düşünmektedir. Bu amaçla yurtdışındaki futbol kulüplerini getiren acentelerle iş birliği yaparak konaklama işletmesinin Sport Center bölümlerinde bir turnuvaya sponsor olmuştur. Bu etkinlik için \%18 KDV hariç 180.000 TL banka aracığıyla ödenmiştir.

\begin{tabular}{|c|c|c|}
\hline $\begin{array}{l}\text { 760 PAZARLAMA SATIŞ ve DAĞITIM GIDERLERİ } \\
\text { 760.05.1 Kongre Sponsorluk Giderleri } \\
\text { 191 İNDİRILECEK KDV HS. } \\
\text { 191.01.03 \%18İndirilecek KDV } \\
102 \text { BANKALAR }\end{array}$ & $\begin{array}{r}18.000 \\
3240\end{array}$ & 21.240 \\
\hline
\end{tabular}

\subsubsection{Dişsal Maliyetler}

Dışsal maliyetler, üretilmekte olan mal ve hizmetlerin pazar fiyatına dahil edilmeyen maliyetleridir. Çevre muhasebesinin en temel amacı sosyal maliyetlerin özel maliyetlere dönüştürülerek maliyet hesaplarına dahil edilmesini sağlamaktır (Çetin vd., 2004: 42). Dışsal maliyetler genel olarak tablo 1'deki gibi kabul görmektedir. 
Tablo: 1. Çevresel Maliyetlerin Dağılımı.

\begin{tabular}{|l|l|l|}
\hline Azaltma Maliyetleri & Kullanma Maliyetleri & Zarar Maliyetleri \\
\hline Çevre Planlaması & Hava Maliyeti & Hava Kirliliği \\
\hline Süreç Kontrol & Su Maliyeti & Su Kirliliği \\
\hline Emisyon Ölçüm Cihazları & Toprak Maliyeti & Görüntü Kirliliği \\
\hline Çevreye Zararsı Mamul Tasarım Geliştirme & Gürültü Maliyeti & Cezalar ve Tazminatlar \\
\hline Geri Dönüşüm Tasarımları & Görüntü Maliyeti & Çevre Temizleme \\
\hline Çevreye Zararsı Ambalaj Geliştirme & Doğal Gaz Maliyeti & Şikayet Araştırmaları \\
\hline Çevre Geliştirme & Petrol Maliyeti & Kefalet Ve Garanti Giderleri \\
\hline Çevresel Eğitim & Kömür Maliyeti & Satış Azalmaları \\
\hline Biyolog, Kimyager Hizmetleri & Enerji Maliyeti & Diğer Zarar Maliyetleri \\
\hline Çevre Mühendislik Hizmetleri & & \\
\hline Çevre Raporları & & \\
\hline Çevre Etkileri & & \\
\hline Çevre Güvenirlik & & \\
\hline Çevre Yönetim Sistemi & & \\
\hline Çevre Denetimi & & \\
\hline
\end{tabular}

Kaynak: Özbirecikli ve Melek, 2002: 85.

\subsubsection{Azaltma/Önleme Maliyetleri}

İşletmelerin çevresel sorunlarını önlemek ya da bu sorunları en aza indirmek amacıyla mamulün tasarlanmasından yok edilmesi veya güvenli bir yerde toplanmasına kadar olan tüm yaşam sürecinin planlanması yürürlüğe konması için katlanmak zorunda oldukları maliyetlerdir (Çalış, 2013:183). Bu doğrultuda konaklama işletmesi çevrenin korunması ve çevreye verilen zararın azaltılması amacıyla işletmeden çıkan çöplerin toplama zamanına kadar bu çöplerden çıkacak kokuların çevreye zarar vermemesi ve rahatsız etmemesi için soğutmalı çöp biriktirme tesisi yaptırmıştır. Bu tesis yapımı nedeniyle 42.000 TL maliyete katlanmıştır. \%18 KDV ilave edilerek bankadaki hesaptan ödenmiş ve şu şekilde kayıt altına almıştır.

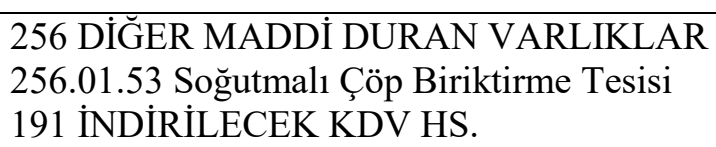

\subsubsection{Kullanma Maliyetleri}

İşletmeler çevre kaynaklarından genellikle yasal sınırlar içerisinde yararlandıkları için herhangi bir bedel ödememektedir. Hava, su, toprak maliyetleri, gürültü, görüntü maliyetleri, enerji maliyetleri vb. maliyetler kullanma maliyetlerine örnek olarak gösterilebilir (Kurtlu, 2017: 313). Konaklama işletmesi de bu doğrultuda Mart 2019 dönemine ait doğal kaynak kullanım bedeli olarak \% $18 \mathrm{KDV}$ hariç $100.000 \mathrm{TL}$ su faturası için çek ciro etmiştir. Bu kullanma maliyeti şu şekilde kayıt altına alınmıştır.

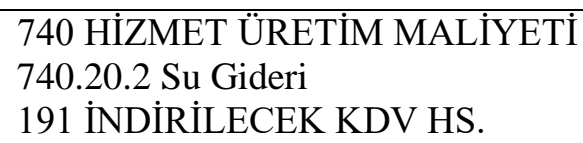

101 ALINAN CEEKLER

\subsubsection{Zarar Maliyetleri}

Zarar maliyetleri, çevresel kirlenmeden sonra (ceza veya tazminat) ortaya çıkan çevreye katkısı olmayan ve doğrudan gider veya zarara dönüşen maliyetler olarak ifade edilmektedir. Zarar maliyetlerinin belirlenebilmesi için ölçülebilir unsurların varlıklarının olması gerekmektedir. Çevreye yayılan gaz, sebep olunan gürültü ve bunun gibi durumlar sonucunda olumsuz etkilenen çevresel faktörler için ölçülebilir bir uygulama mümkün görülmemektedir (Çalış, 2013: 184). Konaklama işletmesi de havuz suyunun analizi sonucunda kullanılan kimyasal temizleyicilerin insan sağlığına 
zararlı olduğu tespit edilmiştir. Buna istinaden $10.000+\% 18$ KDV ceza yazılmış olup ödeme nakit yapılmış ve bu işlem şu şekilde kayıtlanmıştır.

\begin{tabular}{|l|r|r|}
\hline 770 GENEL YÖNETIM GIDERLERİ & 10,000 & \\
770.05 Çevre Temizlik & 1,800 & \\
191 İNDİRİLECEK KDV HS. & & \\
$191.01 .03 \% 18$ İndirilecek KDV & & 11,800 \\
\multicolumn{1}{|l|}{100 KASA } & & \\
\hline
\end{tabular}

Ayrıca işletmenin bağlı bulunduğu belediye, işletmenin istemeyerek de olsa çevreye vermiş olduğu kirlilikten dolayı $45.000+\% 18$ KDV çevre temizlik vergisini bankadan ödemiş ve şu şekilde kayıt altına almıştır.

\begin{tabular}{|l|r|r|}
\hline 770 GENEL YÖNETIM GIDERLERİ & 45.000 & \\
770.05.1 Vergi Resim ve Harçlar & 8,100 & \\
191 İNDIRILECEK.KDV HS. & & \\
$\begin{array}{l}\text { 191.01.03 \%18 İndirilecek KDV } \\
\text { 102 BANKALAR } \\
102.01 .1 \text { Y Bankas1 }\end{array}$ & & 53.100 \\
\hline
\end{tabular}

\section{SONUÇ}

Turizm sektörü incelendiğinde aslında ülkeye ekonomik anlamda getirisi en çok sektörlerden birisidir. Hem maddi hem de manevi faydası bulunmaktadır. Gelen turistlerin ülkeleri en iyi şekilde tanımaları ve bunu güzel bir şekilde aktarmaları için gerekli çalışmalar yapılmaktadır. Bu nedenle öncelikle olumlu imajın aktarılması çevrenin yeteri kadar korunmasına bağlıdır. Çevre koruma tesadüfi olarak ortaya çıkan bir kavram değildir. Çevre üzerinde bir etki, bir farklılık ile sonuçlanan işlemler çevresel maliyetlerin de ortaya çıkmasına neden olmaktadır.

Çevresel faaliyetler işletmelerin kuruluş aşamasından başlar ve sektör büyüdükçe çevresel faaliyetler artar. Sektörün gelişmesiyle birlikte kendini geliştirmek için faaliyetlerde bulunan konaklama işletmelerinin çevreye olan etkisi olumlu ve olumsuz olarak artmaktadır. Tabi bu sektördeki işletmeler çevreye vermiş oldukları zararı minimize edebilmek için ilave maliyetlere katlanmaktadır. $\mathrm{Bu}$ maliyetlerin neler olduğu ve muhasebe kayıtlarına nasıl yansıtıldığ bu çalışmada incelenmiştir.

Çevresel maliyetlerin işletmenin toplam maliyetine büyük etkisi vardır. Çünkü konaklama işletmelerinde yer alan maliyet kalemlerinin büyük kısmı konaklama işletmesi içinde ve dıșındaki faaliyetlerden oluşmaktadır. Gerek gelişen turizm koşullarına ayak uydurmak için gerek rekabet koşulları kaynaklı maliyetlerde bulunmaktadır. Toplam maliyetin içerisinde hizmet bedeli olarak personele yapılan harcamaların konaklama işletmelerinin toplam maliyetinin ciddi bir kısmını oluşturduğu ortaya çıkmaktadır. Yani çevreyi korumak için katlanılan çevresel maliyetler de diğer işletmelerde olduğu gibi turizm işletmeleri için çok önemli bir faaliyet haline geldiğini ifade etmek mümkündür.

Konaklama işletmeleri çevreye vermiş oldukları çevresel zararları en aza indirmek ve gerekli önlemleri alabilmek için çalışmalar yapmaktadırlar. Aynı zamanda rekabet koşullarına uyum sağlamaya da çalışmaktadırlar. Buradan turizmin çevreye vermiş olduğu hem yararlı hem de zararlı çevresel faaliyetleri ortaya çıkmıştır. Uygulamada bu tür işletmelerin çevreye yapılan faaliyetlerin muhasebe kayıtlarının nasıl kaydedildiğinin ve maliyetlerin sınıflandırılmasının maliyetleri nasıl etkilediği üzerine yapılan bu çalışmada turizmin aslında çevre için önemini, turizmin her gelişiminde aslında doğa üzerindeki etkisinin arttığını ifade etmek yerinde olacaktır. Çevresel etkiler, çevresel faaliyetlerin oluşumundan başlar gelişmesiyle daha fazla zarar vermeye başlar. İşte buradaki en büyük amaç çevre üzerindeki baskıyı ve çevresel maliyetleri en aza indirmek olmalıdır. Bu durum hem gelecek nesillerin emanetini onlara aktarmaya hem de işletmelerin ilave maliyetlerini minimuma indirmeye yardımcı olacaktır. 


\section{KAYNAKLAR}

Aksu M.\&Özcan S. (2018). Termal Turizm İşletmeleri İle Diğer Konaklama İşletmelerinin Maliyet Yönetimi Açısından Karşılaştırılması: Çanakkale Örneği, Balıkesir Üniversitesi S.B.E. Dergisi, 21(39), 489-509.

Alagöz A.\&Yılmaz B. (2001). Çevre Muhasebesi ve Çevresel Maliyetler, SÜ. İIBF Sosyal ve Ekonomik Araştırmalar Dergisi, 1(1-2), 147-158.

Apalı A. \& Bozcu M. (2018). Konaklama İşletmelerinde Çevre Muhasebesi, Gazi Kitabevi.

Aslanertik B. E. \& Özgel I. (2007). Konaklama işletmesi İşletmelerinde Çevresel Muhasebe, İşletme Fakültesi Dergisi, 8(2), 163-179.

Atabey, N. A.\& Parlakkaya R.\&Alagöz A. (2001). Genel Muhasebe, Dizgi Ofset.

Atmaca, M.\&Yılmaz, B. (2011). Konaklama İşletmelerinin Faaliyetlerinde Maliyet Kontrolünün Etkileri: Marmara Bölgesinde Faaliyet Gösteren Beş Yıldızlı Oteller Üzerine Bir Araştırma, Mali Çözüm Dergisi, 108, 15-34.

Aydın S. (2012), Konaklama İşletmelerinde Çevre Muhasebesi Uygulamaları Ve Çevresel Maliyetlerin Yaşam Döngüsü Değerlemesi: Türkiye - Birleşik Krallık Örneği, Muhasebe ve Bilim Dünyası Dergisi, 4, 99-120.

Bekçi İ. (2003), Konaklama Muhasebesi, Süleyman Demirel Üniversitesi Yayın No: 36.

Çalış Y. E. (2013). Çevresel Maliyetlerin Muhasebeleştirilmesi, Marmara Üniversitesi İ.I.B.F. Dergisi, XXXIV (1), 175-190.

Çetin, A.T.,\&Özcan M.\&Yücel R. (2004). Çevre Muhasebesine Genel Bakış, S.Ü. İIBF Sosyal ve Ekonomik Araştırmalar Dergisi, 4(7), 61-76.

Dalgar H.\&Yıldırım F. (2016), Konaklama İşletmelerinde Çevre Maliyetlerinin Muhasebeleştirilmesine Yönelik Bir Araştırma, Mehmet Akif Ersoy Üniversitesi Sosyal Bilimler Enstitüsü Dergisi, $8(16), 1-18$.

Kırlığlu, H.\& Can, A. V. (1998). Çevre Muhasebesi, Değiş̧im Yayınları.

Kirk, D. (1998). Attitudes to Environmental Management Held by a Group of Hotel Managers in Edinburgh. International Journal of Hospitality Management. 17 (1), 33-47.

Korukoğlu A. (2011). İşletmelerde Çevre Muhasebesi: İzmir İli Uygulaması, Ege Akademik Baklş, 1, 81-89.

Kurtlu A. (2017). Çevresel Maliyetlerin Faaliyet Tabanlı Maliyetleme Yöntemi ile Belirlenmesi ve Bir Uygulama, Yönetim ve Ekonomi Dergisi, 24(2), 309-325.

Lazol İ.\&Muğal E.\&Yücel Y. (2008). Sürdürülebilir Bir Çevre İçin Çevre Muhasebesi ve KOBİ’lere Yönelik Bir Araştırma, Muhasebe ve Finansman Dergisi, 38, 56-69.

Mutlu Ç.\&Yıldız M.S. (2015). Konaklama İşletmelerindeki Çevre Yönetimi Uygulamalarının Ve Etkilerinin irdelenmesi: Alanyada Faaliyet Gösteren 5 ve 4 Yıldızlı Konaklama İşletmelerinde Bir Araştırma, Akademik Bakış Uluslararası Hakemli Sosyal Bilimler Dergisi 49, 107-126.

Özbirecikli M. \& Melek Z. (2002). Çevre Muhasebesi ve Çevresel Maliyetlerin Maliyet Muhasebesi Sistemine Etkileri: Bir Araştırma, Muhasebe ve Finansman Dergisi, 14, 82-91.

Sancar, M.F.\&Kutukız D.\&Uslu A. (2015), Konaklama İşletmelerinin Çevre Muhasebesine Bakış Açıları: Güneydoğu Anadolu Bölgesi Örneği, Verimlilik Dergisi, 3, 67-86.

Tanc1 N. (2012). İşletmelerde Çevresel Maliyetlerin Belirlenmesi, Muhasebeleştirilmesi ve Raporlanmas1: Bir Süt Endüstrisi İşletmesinde Örnek Uygulama, Yayımlanmamış Yüksek Lisans Tezi. 